\title{
Antecedents of consumers' decision postponement on purchasing fast fashion brands
}

\author{
Hye-Jung Park ${ }^{\dagger}$ \\ Dept. of Consilience, Korea Polytechnic University, Korea \\ 패스트 패션 브랜드에 대한 소비자 의사결정 연기의 선행변수 \\ 박 혜 정 ${ }^{\dagger}$ \\ 한국산업기술대학교 지식융합학부
}

\begin{abstract}
The purpose of this study is to identify the antecedents of consumers' decision postponement on purchasing fast fashion brands. Ongoing search behavior, overchoice confusion, and similarity confusion were considered as antecedents. It was hypothesized that ongoing search behavior influences decision postponement both directly and indirectly through overchoice confusion and similarity confusion. Data were gathered by surveying university students in Seoul, using convenience sampling. Three hundred five questionnaires were used in the statistical analysis, which were exploratory factor analysis using SPSS and confirmatory factor analysis and path analysis using AMOS. Factor analysis proved that ongoing search behavior, overchoice confusion, similarity confusion, and decision postponement were uni-dimensions. Tests of the hypothesized path proved that ongoing search behavior influences decision postponement indirectly through overchoice confusion. In addition, similarity confusion influences decision postponement. The results suggest some confusion reduction strategies for marketers of fast fashion brands. Suggestions for future study are also discussed.
\end{abstract}

Keywords: decision postponement(의사결정 연기), ongoing search behavior(지속적 탐색행동), overchoice confusion (선택과잉 혼란), similarity confusion(유사성 혼란)

\section{Introduction}

구매환경에서 의사결정과 관련된 정보가 끊임없 이 제공됨에 따라 소비자 혼란은 중요한 문제가 되 고 있다(Mitchell \& Papavassiliou, 1999). Walsh et al.(2007)은 2000년대를 넘어서면서 경쟁적 시장환 경의 특징을 선택의 과잉과 마케팅 커뮤니케이션 의 홍수, 정보의 복잡성, 브랜드간 차이 감소의 증 가라고 하였다. 그들은 그 결과로 소비자들은 구매 를 위한 정보처리 과정에서 혼란을 느끼는 것이 당 연하므로 소비자의 혼란이 마케터와 소비자에게 중

\footnotetext{
Received 18 August 2014, revised 29 September 2014, accepted 6 October 2014.

${ }^{\dagger}$ Corresponding author (hpark@kpu.ac.kr)

This is an Open Access article distributed under the terms of the Creative Commons Attribution Non-Commercial License (http://creativecommons.org/licenses/by-nc/3.0) which permits unrestricted non-commercial use, distribution, and reproduction in any medium, provided the original work is properly cited.
} 
요한 문제로 대두되고 있으나, 이에 대한 연구가 소 홀함을 지적하였다. Mick et al.(2004)은 소비자에게 다양한 선택을 주는 마케팅 환경이 소비자에게 미 치는 부정적인 결과를 밝힌 선행연구들을 제시하면 서, 선진국에서의 소비자의 선택 초과잉(hyperchoice) 은 초기에는 소비자에게 매력적으로 보이나 결과 적으로는 소비자를 불만족하게 한다고 하였다. 그 들은 선택 초과잉이 소비자에게 혼란을 주고, 후회 를 야기시켜서 소비자의 도덕적 감정과 행동을 저 하시킨다고 강조하였다. 선택과잉에 대한 소비자 혼란에 대하여 Mitchell and Papavassiliou(1999)는 소비자 혼란을 야기시키는 마케팅 원천으로 제품 과 매장의 선택과잉, 제품의 유사성, 마케팅 커뮤니 케이션을 통해 전달되는 모호한, 호도하는, 부적절한 정보의 세 가지를 제시하였다. Sproles and Kendall (1986)에 의해 선택과잉으로 인한 의사결정 혼란에 대한 연구가 시작되었는데, Mitchell and Papavassiliou (1999)는 브랜드 책임자가 소비자의 혼란을 인식하 고 혼란을 감소시킬 수 있는 전략수립과 공공정책 이 필요하다는 것을 강조하였다. 또한 지난 20년 동안 소비자의 브랜드 혼란에 대한 다양한 연구가 진행되 었으나, 선택과잉(overchoice)은 정보과잉(information overload)에서 시작되었으며, 상대적으로 새로운 개 념이라고 하였다. 특히 그들은 구매포기를 소비자 혼란 결과의 하나로 제시하고, 소비자 스스로가 사 용하는 혼란 감소(confusion reduction) 전략 중 하 나가 구매포기 또는 구매 연기라고 하였다. Walsh et al.(2007)도 의사결정 연기가 기업에 매우 심각한 결과를 초래한다고 하고, 소비자 혼란이 의사결정 연기에 미치는 영향을 밝혔다. 따라서 본 연구는 소비자의 구매 의사결정 연기에 영향을 미치는 선 행변수로서 소비자 혼란인 소비자의 선택과잉 혼 란과 유사성 혼란을 선정하였다.

패스트 패션은 소비자 입장에서는 최신 유행스 타일의 옷을 저렴하게 구매할 수 있으므로(Kang \& Sung, 2010), 최신 유행의 패션을 합리적 가격에 구 입하여 적당히 입기를 즐기는 소비자들에게 많은 인기를 끌며, 최근 패션업계의 중요한 이슈로 떠오 르고 있다(Kim, 2007). Lim et al.(2008)에 의하면 인 터넷을 통한 구매의 용이성, 유통 채널의 다양화, 패 션 유행의 동시적 확산의 가속화 등으로 인해 젊은
소비자들은 끊임없이 변화하는 새로운 패션 제품에 대해서 강한 호기심을 보이며, 최신 트랜드를 즉각 적으로 반영한 저렴한 가격의 패스트 패션을 선호 한다고 한다. 그러나 패스트 패션 브랜드들은 다른 브랜드들과 다르게 최신 트렌드를 즉각 반영해서 제품화하는 차별적 특징으로 인해 트렌디한 이미 지 외에 브랜드 고유의 차별화된 이미지를 갖기 힘 들다. 따라서 패스트 패션이 지나치게 유행에 민감 해서 공장에서 찍어낸 듯한 디자인으로 패션의 획 일성을 지향한다는 것이 문제점으로 지적된다(“A new alternative", 2011). 이러한 과열된 패스트 패션 의 상품화가 디자이너의 창의성과 기술이 접목된 패션의 소중한 가치를 저해할 가능성이 있으며, 개 인의 개성과 감각을 퇴화시킬 수도 있다(“A new alternative", 2011)는 부정적인 시각이 지배적이다. 이러한 부정적인 시각과 일치하듯이, 베이직한 제품 구성을 갖춘 유니클로(UNIQIO)를 제외하고는 글로 벌 패스트 패션 브랜드인 Zara, H\&M, Forever 21, Mango 등과 국내 패스트 패션 브랜드인 스파오, 미 쏘, 에잇세컨즈, 탑텐 등의 수 많은 패스트 패션 브 랜드들은 고유의 차별화된 브랜드 특성을 갖고 있 지 않다. 따라서 모든 패스트 패션 브랜드들이 수 많은 매장과 정보로 소비자에게 접근하며, 한 시즌 의 유행을 반영한 소량다품종의 유사한 제품을 동 시다발적으로 소비자에게 제시한 결과, 브랜드, 매 장, 제품, 정보의 선택과잉과 함께 브랜드의 유사성 으로 인해 소비자가 혼란스러운 것이 현실이다. 선 택과잉과 유사성의 한계점으로 인해 최근에는 패 스트 패션 브랜드 중에서 유명 디자이너와의 협업 등으로 한시적으로나마 디자이너 고유의 특성을 브랜드 및 제품에 투영하는 것을 시도하고 있는 것 으로 보여진다. 예들 들면, 대량으로 쏟아지는 유사 하고 비슷한 패스트 패션 속에서 소비자들에게 차 별화된 디자인과 컬러를 선보이느냐가 관건인데 (Jang, 2014), 유명 디자이너와 협업은 다른 SPA브 랜드와 차별화되는 장점이라고 $\mathrm{H} \& \mathrm{M}$ 은 강조한다 (Chae, 2014).

패스트 패션 브랜드에 대한 선택과잉과 유사성 에 대한 혼란을 간과하고, 대부분의 연구(Byun \& Sternquist, 2008; Park, 2013)들이 소비자의 구매를 유도하는 패스트 패션 브랜드 전략의 유효성을 밝 
히는데 주력하고 있다. 즉, 패스트 패션 브랜드에 대한 소비자행동에 대한 연구가 다양하게 시도되 고 있으나, 패스트 패션 브랜드 자체의 문제점이 소비자 행동에 미치는 영향에 대한 연구는 없다. 패스트 패션 브랜드의 계속적인 성장을 위해서는 패스트 패션 브랜드의 문제점인 선택과잉과 브랜 드 유사성이 구매 의사결정 연기에 미치는 영향을 밝히고 이에 대처하기 위한 방안을 연구할 필요가 있다. 따라서 본 연구는 선택과잉과 유사성으로 인 한 소비자 혼란이 구매 의사결정 연기에 미치는 영 향을 밝히는데 있어서 패스트 패션 브랜드로 한정 하여 실시하였다.

현재 정보환경은 정보원천과 정보제공자의 급증, 정보접근 방법의 다양성, 다양한 원천으로부터의 내용의 중복으로 특징 지워진다(Parbha et al., 2007). 이러한 과잉(overloaded) 정보환경에서 많은 정보 사용자들은 정보의 부적당함과 불안감을 느끼면서 정보에 대한 필요를 만족시킬 때까지 지속적인 정보 탐색을 한다(Parbha et al., 2007). Parbha et al.(2007) 은 이러한 복잡한 정보환경에서 개인들이 정보욕 구(information need)를 만족시키기 위해 지속적인 탐색을 하므로 이에 대한 이해가 절실하다고 강조 하였다. 그런데 패션은 변화의 속성을 갖고 있다. 심지어 하나의 트렌드가 형성되어도 이 트렌드를 소비자가 수용하는 과정에서 지속적으로는 업데이 트 되며, 이러한 업데이트 과정은 트렌드가 쇠퇴기 에 이를 때까지 계속된다(Reamy et al., 2013/2014). 즉, 패션은 변화의 속성으로 인해 정보 자체가 끊 임없이 변화하므로 정보욕구가 충족될 수 없어서 지속적인 탐색을 할 수밖에 없다. 따라서 타 제품 과의 차별적인 패션제품의 특징으로 인해 의류학 에서는 패션에 대한 소비자의 지속적 탐색에 대한 중요성을 인식하고, 소비자 행동에 미치는 영향을 밝혀야 하나, 이에 대한 연구는 미흡하다. 본 연구 는 패션제품의 특징으로 인해 지속적 탐색행동을 의사결정 연기의 선정변수로 선정하였는데, 소비자 의 다양한 특성 중에서 패션에 대한 지속적 탐색행 동은 패스트 패션 브랜드의 문제점인 선택과잉과 브랜드의 유사성의 인지에 영향을 주고, 의사결정 연기에 영향을 줄 것으로 보인다. 따라서 패션에 대한 지속적 탐색행동이 구매 의사결정 연기에 직
접적인 영향을 줌과 동시에 선택과잉 혼란과 유사성 혼란을 통해서 간접적인 영향을 준다는 경로를 설정 한 연구모형을 제시하고, 이를 검증하고자 한다.

\section{Background}

\section{Decision postponement}

소비자는 다양한 이유로 인해 구매 의사결정을 연 기한다. 세계적 금융위기와 같은 거시적 환경으로 인해 의사결정을 연기하기도 하지만, 제품과 관련 된 미시적 환경에 의해서도 연기한다. 의사결정 연기를 유발하는 요인으로서 의사결정 어려움(decision difficulty)이 있는데, Thompson et al.(2009)은 소비 자의 정신적 시뮬레이션이 구매행동을 방해한다고 보았다. 그는 과정 지향적인 사고(process-oriented thinking)가 방법과 결과 효과의 두 가지 모두에 집 중하기 때문에 바람직함(desirability)과 가능함(feasibility) 사이에 상당한 교환 조건(trade-off)에 직면하 면 의사결정 어려움이 더욱 커진다는 것을 밝혔다. Greenleaf and Lehmann(1995)은 대부분의 소비자가 정보를 수집하고, 대안을 평가하며, 구매장소를 결 정하는데 많은 시간을 소비한다는 것을 강조하고, 이러한 시간을 의사결정 시간이라고 하였다. 그리 고 정보탐색에 대해서는 선행연구가 많이 이루어 졌는데 비해, 소비자의 의사결정 시간이 한 달이나 몇 년이 걸리는 이유에 대해서는 연구가 없으므로 이를 밝힐 필요가 있다고 지적하였다.

$\operatorname{Kim}(2008)$ 은 구매 의사결정 연기의 이유에 대한 선행연구들이 두 가지 관점에서 이루어졌다고 하 였다. 첫째, 제품에 대한 정보와 대안을 더 찾거나 신중한 구매를 하기 위한 것으로서 구매 결정 과정 단계에 초점이 이루어졌다. 즉, 지속적 정보탐색은 의사결정 연기에 영향을 주었다. 둘째, 최상의 선택 을 위해서 선택의 어려움과 같이 구매 시 고려하는 대안들에 초점이 이루어졌다. 특히 구매 결정 과정 단계에서의 정보탐색에 대한 연구로서, Huffman and Kahn(1998)은 소비자가 느끼는 정보의 과다함은 소 비자로 하여금 구매를 연기하게 만든다고 하였다. 그리고 소비자의 구매 연기에는 다양한 요인들이 작용하는데, 구매를 원하는 상품의 품질, 불충분한 상품정보, 불만족한 상품구색, 상품평가의 어려움 
이라고 하였다. 즉, 소비자 혼란이 의사결정 연기에 영향을 주었다.

의류학에서 구매 의사결정 연기에 대한 연구들 이 최근에 이루어졌다. 국외 연구로는 윤리적 의류 (ethical clothing), 국내 연구로는 인터넷 쇼핑몰에 서의 구매 의사결정 연기로 제한되어 진행되었다. Hassan et al.(2013)은 패션 기업들이 기본적으로 실 시해야 하는 마케팅 실행 중 하나로서, '윤리(ethical)', 'organic(유기농)', 'fair trade(공정무역)' 용어들에 대 한 정확한 정의와 차이를 소비자에게 인지시키지 않는 것이 소비자에게 윤리적 의류를 구매할 때 불 확실성을 느끼게 한다고 하였다. 그리고 윤리적 소 비에서 소비자가 느끼는 불확실성을 이해하는 것 이 소비자의 태도와 행동의 차이에 깔려있는 구조를 이해하게 한다고 강조하였다. 그리고 심층인터뷰와 표적집단 면접을 통해 윤리적 의류의 구매 의사결 정에 있어서 복잡함(complexity), 모호함(ambiguity), 갈등(conflict), 신뢰성(Credibility)과 같은 불확실성 을 야기시키는 요인들로 인해 구매 의사결정을 연 기한다고 것을 밝혔다. 국내 연구로서 Lee(2013)는 인터넷 쇼핑몰에서 선택의 어려움이 제품 선택 과 정에서의 복잡성과 불확실성, 상품구색 및 정보, 이 전 구매 시의 불만족 경험의 세 가지 요인임을 밝 히고, 이러한 선택의 어려움이 소비자가 구매 의사 결정 연기에 정적인 영향을 준다는 것을 밝혔다. 패션상품은 유행이라는 고유의 특성으로 인해 매 시즌 유사한 스타일의 제품을 제시하게 되어, 소비 자들이 선택의 어려움이 가중되고 있다고 지적하 고, 인터넷 상에서 제품 구매 시 이러한 현상은 더 욱 심각하다고 하였다. 또한 그는 인터넷에서 유행 스타일의 상품에 대한 정보가 실시간으로 제공되 고, 인터넷 쇼핑몰 별로 디자인, 품질 및 가격에 대 한 차이가 없어서 소비자들의 선택의 어려움은 더 욱 커지고 있다고 하고, 이에 대한 연구의 필요성 을 제기하였다. $\operatorname{Kim}(2008)$ 은 의류제품은 빠른 유행 의 변화와 구매에 따른 위험지각이 타 제품보다 크 기 때문에 구매 의사결정 연기를 한다고 강조하면 서 의류제품의 구매 연기에 대한 연구의 필요성을 제시하였다. 그리고 인터넷 의류의 구매 연기 요인 으로서 성과적 위험지각, 비교쇼핑 성향, 사회적 위 험지각, 경제적 쇼핑, 불확실성, 시장변화 기대, 상
품 불만족, 소극적 쇼핑성향이 있음을 밝혔다. 이상 의 국내 연구들은 인터넷 쇼핑몰에서의 구매 의사 결정 연기에 대한 연구이나, 인터넷 쇼핑몰이라는 쇼핑환경 외에도 다양한 환경과 변수의 영향을 밝 힐 필요가 있다. 따라서 본 연구는 인터넷 쇼핑몰 이 아닌 오프라인 매장에서의 구매 의사결정 연기 를 밝힌다는 것에 의의가 있다.

\section{Ongoing search behavior}

현재 정보환경의 특징은 정보원천과 정보제공 자의 급증, 정보접근 방법의 다양성, 다양한 원천 으로부터의 내용의 중복이다(Parbha et al., 2007). 이러한 과잉(overloaded) 정보환경에서 많은 정보 사용자들은 정보의 부적당함과 불안감을 느끼면 서 정보에 대한 필요를 만족시킬 때까지 지속적인 정보탐색을 한다(Parbha et al., 2007). Parbha et al. (2007)은 이러한 복잡한 정보환경에서 개인들이 정 보욕구(information need)를 만족시키기 위해 지속 적인 탐색을 하므로, 이에 대한 이해가 절실하다 고 강조하였다. 그런데 패션의 변화 속성으로 인 해 끓임없이 정보가 변화하므로 소비자의 정보욕 구가 충족될 수 없으므로 지속적인 탐색을 할 수 밖에 없다.

Tauber(1972)는 소비자가 제품 획득을 위해서만이 아니고 심리적 필요를 만족시키기 위해 쇼핑을 한다 고 하였다. 즉, 쇼핑이 실제 구매와 상관없이 행하여 진다고 지적하였다. Bellenger and Korgoankar(1980)도 대부분의 소비자들이 구매와 상관없이 쇼핑 그 자체 를 즐긴다는 것을 밝혔다. 그리고 Watchravesringkan and Yurchisin(2007)은 젊은 소비자가 쇼핑몰에 가는 이 유가 쇼핑을 하기 위해서가 아니라, 제품에 대한 지식을 얻기 위해서라고 하였다. 즉, 쇼핑은 구매와 관계없이 행하여질 수 있는 중요한 지속적 정보탐색 활동으로 간주된다. 특히 Bellenger and Korgoankar (1980)는 미국소비자와 한국소비자를 대상으로 의 류 쇼핑상황에서 지속적 탐색 활동은 매장 둘러보 기, 쇼윈도우 구경하기, 새로운 트렌드와 스타일을 알기 위해 패션잡지 보기, 친구들과 새로운 패션 트렌드 이야기하기, 제품에 대한 정보를 얻기 위하 여 판매원과 이야기하기의 활동을 포함한다고 하 였다. 이들이 구매 상황 내에서의 다양한 활동을 
지속적 정보탐색으로 본 반면, Bloch et al.(1986)은 지속적 탐색은 새로운 스타일을 알기 위해 패션잡 지를 읽거나 친구들과 패션 트렌드에 대해 대화하 는 것 등 구매 상황 밖에서의 다양한 활동을 포함 시켜야 한다고 하였다. 그리고 실증적으로 지속적 탐 색이 실용적, 정보적 동기보다 오락적(recreational), 쾌락적 동기와 더 관련이 크다는 것을 밝혔다. 그 결과로 탐색 활동은 구매의도와 관련된 것만 고려 하지 말고 매장 밖에서의 다양한 활동도 포함하여 야 한다고 하였다. 따라서 그들은 지속적 탐색 활 동을 '특정한 구매의 필요나 의사결정과 관계없는 탐색활동'으로 정의하였다. 국내 소비자를 대상으 로 지속적 정보탐색을 밝힌 Kim and Rhee(2001)도 Bloch et al.(1986)의 정의와 같은 맥락으로 지속적 탐색을 '특별히 구매를 계획하지 않은 상황에서도 미래의 쇼핑을 위해 평소에도 지속적으로 정보를 추구하며, 기억 속에 쇼핑정보를 보유하는 행동'이 라고 정의하였다. 본 연구에서의 지속적 탐색도 이 정의와 같다.

Bloch et al.(1986)은 선행연구들에 근거해서 지 속적 탐색의 동기를 두 가지로 제시하였다. 미래에 유용한 정보를 모으기 위한 것과 즐거움과 오락을 위한 것인데, 이 중에서도 미래에 유용한 정보를 모으는 것은 제품에 대한 지식을 쌓게 한다고 하였 다. 그리고 지속적 탐색은 제품에 대한 관여와 강 한 관계가 있음을 보여주었다. 국내 의류학에서도 관여와 지속적 탐색의 관계에 대한 연구들이 있다. Kim and Rhee(2001)는 여대생을 대상으로 유행선 도력이 지속적 정보탐색에 정적인 영향을 미치는 것을 밝혔다. 또한 Choi(2010)는 여대생을 대상으 로 유행관여가 인터넷을 통한 지속적 정보탐색행 동에 정적인 영향을 미친다는 것을 밝혔다. 이상의 선행연구들에 근거하면, 관여가 있는 소비자가 지 속적 정보 탐색활동을 할 것으로 보인다. 그런데 소비자는 지속적 정보탐색을 하면 제품에 대한 지 식을 더 쌓을 것이다. 즉, 매장 안과 밖에서 지속적 탐색을 하는 소비자는 쌓인 지식으로 인해 브랜드 특성을 비교, 분석할 수 있으므로 패스트 패션 브 랜드의 특성인 선택과잉과 유사성에 대한 혼란을 덜 느끼게 될 것으로 보인다. 따라서 지속적 탐색 행동은 패스트 패션 브랜드의 선택과잉과 유사성
에 따른 혼란에 부적인 영향을 줄 것으로 보고 가 설 1-1과 1-2를 설정하였다.

본 연구에서의 지속적 탐색행동은 패션에 국한 된 지속적 탐색을 의미한다. 본 연구와 같은 지속 적 탐색행동 변수를 사용한 $\operatorname{Park}(2014)$ 은 패션에 대한 지속적 탐색행동은 소비자로 하여금 새로운 트렌드를 인지하게 한다고 하였다. 그리고 패스트 패션 브랜드는 새로운 트렌드를 끊임없이 반영, 제 시하는 것을 가장 중요한 경쟁력으로 삼고 있으므 로 패션에 대한 지속적 탐색은 트렌드를 반영한 패 스트 패션 브랜드 구매태도에 긍정적인 영향을 줄 것으로 보았으나, 유의적인 관계가 나타나지 않았 다. 그런데 지속적 탐색행동이 패스트 패션 브랜드 구매에 미치는 영향을 밝힌 다른 선행연구가 없으 므로 정적인 영향이 나타나지 않은 것에 대한 깊이 있는 이해를 제시할 필요가 있다.

지속적 탐색행동과 관련이 있는 관여와 유사성 혼란에 미치는 영향을 밝힌 선행연구들은 상반된 결과를 나타냈다. Walsh and Mitchell(2005)은 제품 에 대해 관여한 소비자는 브랜드간의 차이를 잘 알 수 있기 때문에 중요한 제품에 대해서는 제품 유사 성을 덜 지각한다고 주장하였다. 즉, 제품에 더 많 이 관여할수록 제품종류의 브랜드에 풍부한 지식 기반을 갖고 있으므로 모방 브랜드들과의 제품 유 사성을 적게 지각할 것이다(Foxman et al., 1992). 이와는 대조적으로 Walsh et al.(2010)은 소비자들 이 처리할 정보의 양이 너무 많으면 모든 브랜드의 차이에 대한 정보를 처리하지 않고, 의사결정을 단 순화한다고 하였다. 그런데 고관여 제품들은 일반 적으로 매우 경쟁적 환경에서 많은 제품의 속성과 혜택을 강조하고 소비자에게 전달하려고 하지만, 소비자들은 고관여 제품에 대해서 관련된 모든 정 보를 이해하고 처리하지 않기 때문에 제품의 유사 성을 더 지각할 것이라고 하고 이를 밝혔다. 본 연 구는 Walsh and Mitchell(2005)의 결과를 바탕으로, 패션에 대해 지속적 탐색행동을 할수록 소비자가 패스트 패션 브랜드의 유사성을 낮게 지각할 것으 로 본다.

가설 1-1. 지속적 패션 탐색행동을 할수록 선택 과잉 혼란이 낮을 것이다. 
가설 1-2. 지속적 패션 탐색행동을 할수록 유사 성 혼란이 낮을 것이다.

$\operatorname{Kim}(2008)$ 은 의류제품은 빠른 유행의 변화와 구 매에 따른 위험지각이 타 제품보다 크기 때문에 구 매 의사결정을 연기한다고 강조하였다. 그러나 패 션에 대한 지속적 탐색을 할수록 빠르게 변화하는 최신 유행과 이를 반영한 제품들을 잘 알기 때문에 위험지각이 더 낮을 것이다. 따라서 지속적 탐색을 할수록 최신유행을 반영한 패스트 패션 브랜드에 대한 구매 의사결정을 연기하지 않을 것이라고 본 다. 가설 $1-3$ 은 다음과 같다.

가설 1-3. 지속적 패션 탐색행동을 할수록 구매 의사결정을 연기하지 않을 것이다.

\section{Consumer confusion}

Turnbull et al.(2000)은 소비자 혼란을 '소비자가 정보처리과정에 있어서 제품/서비스의 다양한 측면 에 대해 올바른 해석을 하는 것에 실패하는 것'으 로 정의하였다. Walsh et al.(2007)은 2000년대를 넘 어서면서 경쟁적 시장환경의 특징을 선택의 과잉 과 마케팅 커뮤니케이션의 홍수, 브랜드간 차이의 감소, 정보의 복잡성과 원천의 증가라고 하였다. 따 라서 소비자들은 구매를 위한 정보처리 과정에서 혼란을 느끼는 것이 당연하다고 하였다. Walsh et al.(2007)은 증가된 시장정보로 인한 소비자의 혼란 이 마케터와 소비자에게 중요한 문제로 대두됨에 도 불구하고, 이에 대한 연구가 미흡함을 지적하며, 소비자의 혼란 경향(consumer confusion proneness) 을 측정하기 위한 척도를 개발하였다. 척도는 다차 원적으로서 유사성(similarity), 과다함(overload), 애 매함(ambiguity)의 세 가지 차원으로 구성되어 있으 며, 차원들은 소비자의 의사결정 연기와 충성 행동 에 유의적인 영향을 주는 것으로 밝혀졌다. 또한 그들은 기업에게 있어서 소비자 혼란은 궁극적으 로는 혼란의 결과와 그 결과들의 경제적 관련성에 기초해서 평가하여야 하다고 지적하였다. 그리고 선행연구들에 의해 소비자 혼란의 결과들은 불만 족, 부정적 구전, 인지적 불일치, 의사결정 연기, 충 성심 감소와 같은 기업이윤에 부정적인 영향을 주
는데, 그 중에서도 의사결정 연기가 기업에게 가장 심각한 결과를 초래한다고 하였다. 그리고 소비자 혼란이 의사결정 연기에 미치는 영향을 밝혔다. 소 비자 혼란에 대해 선행변수와 후속변수를 포함하 여 개념적 모형을 제시한 Mitchell et al.(2005)도 선 택과잉에 대한 혼란과 유사성 혼란으로 인해 구매 를 포기하고, 최종 결과는 선택에 대한 자신감의 감소라고 하였다. 따라서 본 연구는 패스트 패션 브랜드의 특성인 선택과잉과 유사성에 의한 소비 자 혼란이 의사결정 연기에 미치는 영향을 밝히고 자 한다.

소비자 혼란에 대한 연구는 최근에 이르러 다양 한 변수와 관련하여 진행되었지만 제한적이다. 소 비자 혼란에 따른 상표권 침해에 대한 연구(Jacoby \& Morrin, 1998; Miaoulis \& D'amato, 1978), 소매 상들의 자사의 성공한 브랜드에 대한 복제 브랜드 출시가 소비자 혼란에 미치는 영향에 대한 연구 (Balabanis \& Craven, 1997), 에코 레이블이 소비자 혼란에 미치는 영향에 대한 연구(Langer et al., 2008), 제조업자 브랜드(내셔널 브랜드)와 유통업자 브랜 드(프라이빗 브랜드)와의 물리적 특성의 유사함으 로 인한 소비자 혼란에 대한 연구(Loken \& Hinkle, 1986; Kapferer, 1995), 이벤트 스폰서의 과잉과 유 사성에 대한 소비자 혼란에 대한 연구(Sachse et al., 2010), 인터넷에서의 소비자 혼란에 대한 연구(Matzler et al., 2011) 등이 있다.

\section{1) Overchoice confusion}

Walsh et al.(2007)은 과잉 혼란(overload confusion) 은 '소비자가 처리할 수 있는 것보다 많은 제품정 보와 대안들에 직면했을 때의 대안들을 비교하고 이해하는 것에 대한 어려움'을 말한다고 정의하였 다. Sproles and Kendall(1986)은 소비자의 의사결정 스타일의 가장 기본적인 8 가지 특성의 하나로서 선 택과잉으로 인한 혼란이라고 보았다. 그리고 의사 결정 스타일의 8 가지 특성을 개념화하고, 이를 측 정하기 위한 Consumer Styles Inventory(CSI)를 개 발, 제시하였다. 하나의 특성으로서의 선택과잉으 로 인한 혼란은 브랜드, 매장, 소비자 정보의 급증 과 같은 것으로 인해 나타나며, 선택하기에는 많은 브랜드와 매장, 정보가 있다고 지각하여 선택의 어 
려움을 겪는다고 하였다. 또한 Durvasula et al.(1993) 은 의사결정 스타일이란 '소비자가 어떻게 선택하 는지를 보여주는 정신적 성향'이라고 하고, 뉴질랜 드 대학생을 대상으로 의사결정 스타일의 한 요인 으로 선택과잉으로 인한 혼란 요인을 추출하였다. 요인은 Sproles and Kendall(196)과 같은 4문항으로 구성되었다.

최근에 이르러 선택과잉에 대한 부정적인 결과 에 대한 연구가 활발히 진행되고 있으나, 의류학에 서는 이에 대한 연구가 없다. Schweizer et al.(2006) 은 선택의 다양성이 증가함에 따라 소비자는 선택 의 자유를 만끽하기보다는 선택을 더 이상 효율적 으로 할 수 없는 상황에 놓인다고 하였다. 이와 같 은 맥락으로 Iyengar and Lepper(2000)도 현대사회 에서 선택의 폭이 넓을수록 더 좋을 것이라는 일반 적인 믿음에 대하여 실험연구를 통해 선택의 폭이 제한적일 때 구매할 가능성이 더 높다는 것을 밝혔 다. 특히 선택과잉이 의사결정 연기에 미치는 영향 에 대하여, Settle and Alreck(1988)은 과잉은 소비 자의 의사결정을 연기한다고 하였다. 또한 Wang and Shukla(2013)은 대안들과 정보의 과잉으로 인 한 과잉혼란은 선택에 대한 자신감을 감소시킨다 는 것을 밝혔다. 즉, 소비자는 선택을 위한 대안들 을 많이 가질수록 자신들의 선택에 대한 확신이 줄 어들고, 결국에는 의사결정을 연기하게 된다(Chernev, 2003). 그리고 Walsh et al.(2007)은 실증적으로 과 잉선택 혼란이 구매 의사결정 연기에 정적인 영향 을 준다는 것을 밝혔다. 이상의 대부분의 연구들이 브랜드, 매장 과잉혼란보다는 제품 과잉혼란과 정 보 과잉혼란에 초점을 두고 행하여졌다. 그러나 본 연구의 선택 과잉은 브랜드, 매장, 제품, 정보에 대 한 과잉혼란을 모두 포함하는 의미로 사용하였다. 따라서 이러한 포괄적인 선택과잉을 측정하는 Sproles and Kendall(1986)의 척도를 사용하였다. 본 연구는 수많은 패스트 패션 브랜드들이 과잉 매장과 제품, 정보로 접근하면서 소비자는 혼란을 느끼고 구매 의사결정을 연기하게 될 것으로 본다. 이에 따른 가설 2-1은 다음과 같다

가설 2-1. 선택과잉 혼란이 클수록 구매 의사결 정을 연기할 것이다.

\section{2) Similarity confusion}

소비자는 브랜드를 알아보고 차이를 구분하는 데, 종종 시각적 단서에 의존하는데, 유사한 속성을 가진 브랜드들이 시장에 많이 존재해서 소비자에 게 혼란을 일으키게 한다(Wang \& Shukla, 2013). Mitchell et al.(2005)은 브랜드 유사성(brand similarity) 이란 '소비자의 선택에 대한 잠재적 수정과 이해부 족이나 제품/서비스의 지각된 물리적 유사성에 의 해 브랜드에 대해 내리는 올바르지 않은 평가'라고 정의하였다. 의류학에서의 브랜드 유사성에 대한 국내 연구들은 대부분 제품확장 전략의 효과성에 영향을 주는 변수로 국한되어 진행되어 왔다. Kim and Lee(2011)은 패션 브랜드에 대해서 모 브랜드 와 확장제품 간의 지각된 유사성이 확장제품에 대 한 호의성, 구매의도와 같은 패션 브랜드 확장 효 과에 긍정적인 영향을 주는 것을 밝혔다. 이들의 연구에서 지각된 유사성이란 제품 관련 측면인 기 능적인 유사성과 브랜드 퍼스낼리티와 같은 상징 적 속성의 유사성의 두 가지를 모두 포함하여 진행 하였다. Rhee(2009)는 의류 브랜드 확장 시 제품범 주의 유사성이 높을수록 확장제품에 긍정적으로 평가한다는 것을 밝혔다.

유사성 혼란이란 너무 같아서 쉽게 혼란을 느끼 게 되는 광고, 대인간의 의사소통, 매장 환경이나 제품과 같은 자극들로부터 야기된다(Walsh et al., 2007). 즉, 선택과잉의 요소들이 유사한 경우에 소 비자는 브랜드 유사성 혼란을 느끼게 된다고 볼 수 있다. 그런데 유사성 혼란이 소비자의 구매 의사결 정 연기에 미치는 영향에 대해서는 상반된 선행연 구 결과가 있다. 첫째, 유사성 혼란이 구매 의사결 정 연기에 부적 영향을 미친다는 것이다. Walsh et al.(2007)은 소비자들은 브랜드들이 유사하고, 기능 적이나 상징적인 여러 면에서 동등하다고 지각하 면 브랜드들은 서로 대신할 수 있다고 생각하기 때 문에 구매 의사결정을 연기할 필요가 없을 것이라 고 보는 것이 합리적이라고 하였다. 그리고 대부분 의 소비자들이 제조업자 브랜드와 저가의 유사한 브랜드 사이에 품질의 차이를 알아내고 기억하기 어렵다는 것을 밝힌 Warlop et al.(2005)의 연구를 근거로 하였다. 그리고 Walsh et al.(2007)은 소비자 가 저가의 유사한 브랜드에 접하면 사실상 고가의 
제조업자 브랜드에 대해 특정 경험에 있었을 때도 저가의 브랜드에 대해 만족할 만한 이전 소비경험 이 있다고 잘못 생각할 수 있다고 하였다. 그래서 브랜드 유사성 자극에 쉽게 영향을 받는 소비자는 제품의 지각된 물리적 유사성으로 인해 선택을 변 경할 가능성이 있다고 하였다. 그리고 이러한 가정 은 유사성 혼란을 쉽게 느끼는 소비자들은 브랜드 를 알아보고 차별화하는데 있어서 시각적인 단서 에 의존하기 때문에, 유사한 브랜드를 제시하였을 때 오리지널이라고 생각하고, 가짜나 소매점 소유의 브랜드(retailer own-label brand)를 구매할 수 있다 는 것이다. 그리고 유사성 혼란을 하는 소비자들은 광범위한 의사결정을 피하고, 쇼핑과정을 짧게 하 기 위해서 '저가 제품 구매'와 같은 자기만의 체험 적인 의사결정 방법을 이용한다고 하고, 실증적으 로 유사성 혼란이 구매 의사결정 연기에 부적인 영 향을 준다는 것을 밝혔다. 즉, 브랜드 유사성에 대 한 이들의 연구는 고가와 저가의 브랜드로 한정하 여 구매행동에 미치는 영향을 보았다. 그러나 본 연구는 품질이 차이가 없는 비슷한 가격의 패스트 패션 브랜드들로 한정하여 진행되므로, 이들 브랜 드의 유사성으로 인한 혼란의 결과와 다를 것으로 보인다. 본 연구는 Walsh et al.(2007)과 상반된 것 으로서 유사성 혼란이 구매 의사결정 연기에 정적 영향을 미친다는 두 번째 연구결과에 근거한다. 두 번째는 유사성 혼란에 대해 일반적인 관점으로 접 근한 것이다. Mitchell et al.(2005)은 유사성 혼란으 로 인해 구매를 포기하고, 최종 결과는 선택에 대 한 자신감의 감소라고 하였다. 따라서 유사성 혼란 이 구매 의사결정 연기에 정적인 영향을 줄 것이라
고 가설 2-2를 설정하였다.

가설 2-2. 유사성 혼란이 클수록 구매 의사결정 을 연기할 것이다.

\section{Methods}

\section{Hypothesized model}

본 연구는 급성장하고 있는 패스트 패션 브랜드 에 대한 소비자 이해를 제시하기 위하여 패스트 패 션 브랜드의 구매 의사결정 연기에 영향을 미치는 선행변수들을 밝히고자 한다. 선행변수로서 지속적 패션 탐색행동과 선택과잉 혼란, 유사성 혼란을 선 정하여 경로를 설정하였다. 구체적인 경로는 지속 적 패션 탐색행동이 구매 의사결정 연기에 직접적 인 영향을 줄 뿐 아니라, 선택과잉 혼란과 유사성 혼란을 통해서 구매 의사결정 연기에 간접적인 영 향을 준다는 경로를 설정하고, 이를 검증하고자 한 다. 설정된 경로모형은 〈Fig. 1〉과 같으며, 경로에 따른 가설은 다음과 같다.

가설 1-1. 지속적 패션 탐색행동을 할수록 선택 과잉 혼란이 낮을 것이다

가설 1-2. 지속적 패션 탐색행동을 할수록 유사 성 혼란이 낮을 것이다.

가설 1-3. 지속적 패션 탐색행동을 할수록 구매 의사결정을 연기하지 않을 것이다.

가설 2-1. 선택과잉 혼란이 클수록 구매 의사결 정을 연기할 것이다.

가설 2-2. 유사성 혼란이 클수록 구매 의사결정

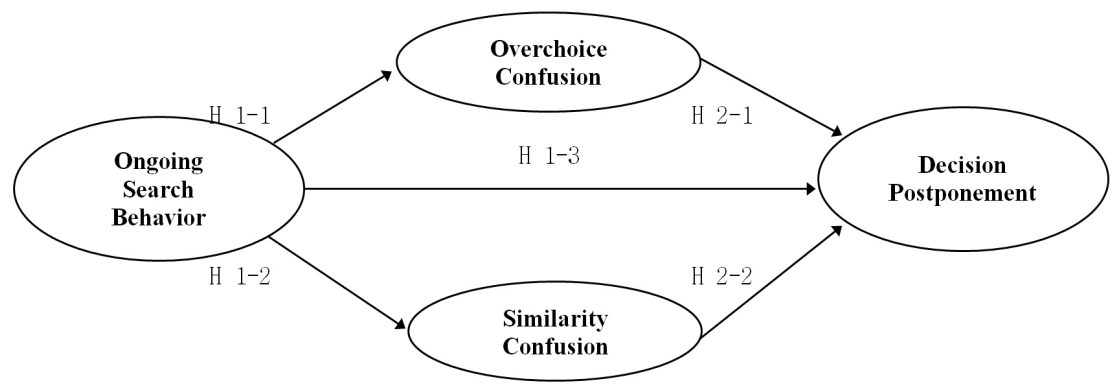

〈Fig. 1〉 Hypothesized model 
을 연기할 것이다.

\section{Measurement and analysis}

설문지는 패션에 대한 지속적 패션 탐색행동, 패 스트 패션 브랜드의 선택과잉과 유사성으로 인한 혼란, 패스트 패션 브랜드에 대한 구매 의사결정 연기 및 인구통계적 변수에 대한 문항을 포함하였 다. 모든 질문문항들에 대한 응답자의 정확한 답을 얻기 위하여 위하여 설문지의 첫 페이지에 패스트 패션 브랜드에 대한 정의와 함께 대표적인 해외와 국내 브랜드들을 예로 제시하였다. 또한 예의 제시 와 일치하도록 패스트 패션은 국내 브랜드와 해외 브랜드를 모두 포함한 것으로 질문한다는 것을 명 시하였다.

지속적 패션 탐색행동은 의복에 대해 제시한 Bloch et al.(1996)의 척도를 Watchravesringkan and Yurchisin (2007)이 수정하여 사용한 7문항을 사용하였다. 선 택과잉 혼란은 Sproles and Kendall(1986)의 소비자 의 8 가지 의사결정 특성을 측정하기 위한 Consumer Styles Inventory(CSI) 척도에서 선택과잉으로 인한 혼란 요인의 4 문항을 이용하였다. Durvasula et al. (1993)은 이들의 척도를 뉴질랜드 대학생을 대상으 로 타당성과 신뢰성을 검증하였는데, 선택과잉으로 인한 혼란 요인으로 같은 4 문항이 추출되었다. 유 사성 혼란은 Walsh et al.(2007)이 소비자의 혼란경 향을 측정하기 위하여 개발한 척도에서 브랜드의 유사성 혼란을 측정한 2 문항을 이용하였다. 의사결 정 연기는 Walsh et al.(2007)의 4문항으로 구성된 척도를 사용하였다. 인구통계적 변수를 제외한 모 든 변수들은 5점 Likert 형으로 측정되었으며, 1점 은 ‘전혀 아니다'에서 5 점은 '매우 그렇다'로 측정 되었다. 따라서 모든 변수가 점수가 높을수록 변수 의 성향이 높은 것을 의미한다.

인구통계적 변수를 제외한 모든 변수들에 대하 여 탐험적 요인분석(Exploratory Factor Analysis)을 실시한 후, 탐험적 요인분석의 결과에 대하여 확인 적 요인분석(Confirmatory Factor Analysis)을 실시 하였다. 탐험적 요인분석의 통계처리는 SPSS 18.0 통계 패키지를 이용해 주성분분석과 베리맥스 회 전방법을 사용하였다. 확인적 요인분석과 가설화된 경로구조 분석을 위하여 구조방정식 모형(Structural
Equation Modeling)을 이용하였는데, 이를 위하여 AMOS 18.0 프로그램을 사용하였다. 모수 추정방 법은 최대우도비 추정방법을 이용하였다. 그 외에 신뢰도 분석과 기술통계를 실시하였다.

\section{Data collection}

본 연구의 자료 수집을 위하여 서울과 주변 신도 시에 거주하는 20 대 대학생을 편의 추출하여 설문 조사하였다. 회수된 설문지 중 응답이 불성실한 설 문지를 제외한 305 부를 분석에 사용하였다. 통계처 리에 사용된 응답자의 평균연령은 만 22.03 세 $(\mathrm{SD}=$ 2.27 )였으며, 여성은 153 명(50.2\%), 남성은 152 명(49.8\%) 이었다. 응답자의 지속적 탐색행동의 평균은 $3.04(\mathrm{SD}=$ $.75)$, 선택과잉 혼란의 평균은 $3.09(\mathrm{SD}=.85)$, 유사성 혼란의 평균은 $3.24(\mathrm{SD}=.92)$, 구매 의사결정 연기의 평균은 $3.12(\mathrm{SD}=.81)$ 로서 모든 변수들이 중간 값 (median)인 3과 거의 같거나 조금 높게 나타났다. 따라서 본 연구의 응답자는 지속적 탐색행동, 선택 과잉과 유사성에 따른 혼란, 구매 의사결정 연기가 중도에 가까운 성향을 갖고 있다고 할 수 있다.

\section{Results and Discussion}

\section{Exploratory factor analysis}

인구통계적 변수를 제외한 모든 변수들에 대해 탐험적 요인분석을 실시한 결과, 모든 변수들이 각 각 한 개의 차원(uni-dimension)으로 나타났다. 요인 분석 결과와 신뢰도분석 결과는 〈Table 1)과 같다. 지속적 탐색행동, 선택과잉 혼란, 유사성 혼란, 구 매 의사결정 연기의 각각의 총 설명력이 $53.50 \%$, $66.41 \%, 81.34 \%, 62.85 \%$ 로 모든 변수들이 $50 \%$ 이 상으로 나타났다. 또한 Cronbach's $\alpha$ 는 지속적 탐 색행동은 .71 , 선택과잉 혼란은 .83 , 유사성 혼란은 .77 , 구매 의사결정 연기는 .80 으로 나타나서 측정 도구의 내적 타당성은 문제가 없다고 본다.

\section{Confirmatory factor analysis}

제시된 모형의 적합성을 분석하기 전에 변수들 에 대한 탐색적 요인분석 결과를 검증하기 위하여 확인적 요인분석을 실시하였다. 모두 단일차원으로 나타났으므로 각각 1 요인모형으로 실시하였는데, 
$\langle$ Table 1〉 Factor analysis

\begin{tabular}{|c|c|c|}
\hline Measure & Item & $\begin{array}{l}\text { Factor } \\
\text { loading }\end{array}$ \\
\hline \multirow{5}{*}{$\begin{array}{l}\text { Ongoing search } \\
\text { behavior }\end{array}$} & $\begin{array}{l}\text { Often visit clothing stores or departments, just to look around or get information rather than } \\
\text { to make a specific purchase. }\end{array}$ & .77 \\
\hline & Often read fashion magazines to get information about trends/styles. & .76 \\
\hline & $\begin{array}{l}\text { Often talk to friends or acquaintances to get information or advice concerning clothing and } \\
\text { clothing styles. }\end{array}$ & .73 \\
\hline & Often discuss with retail salespersons to get information during store visit. & .66 \\
\hline & Eigenvalue $=1.14 \quad$ Total variance explained $=53.50 \quad$ Cronbach's $\alpha=.71$ & \\
\hline \multirow{5}{*}{$\begin{array}{l}\text { Overchoice } \\
\text { confusion }\end{array}$} & Sometimes it's hard to choose which stores to shop. & .85 \\
\hline & The store I learn about products, the harder it seems to choose the best. & .84 \\
\hline & All the information I get on different products confuses me. & .84 \\
\hline & There are so many brands to choose from that often I feel confused. & .73 \\
\hline & Eigenvalue $=2.66 \quad$ Total variance explained $=66.41 \quad$ Cronbach's $\alpha=.83$ & \\
\hline \multirow{3}{*}{$\begin{array}{l}\text { Similarity } \\
\text { confusion }\end{array}$} & $\begin{array}{l}\text { Some brands look so similar that it is uncertain whether they are made by the same } \\
\text { manufacturer or not. }\end{array}$ & .90 \\
\hline & Most brands are very similar and are therefore hard to distinguish. & .90 \\
\hline & Eigenvalue $=1.63 \quad$ Total variance explained $=81.34 \quad$ Cronbach's $\alpha=.77$ & \\
\hline \multirow{5}{*}{$\begin{array}{c}\text { Decision } \\
\text { postponement }\end{array}$} & Sometimes when making a purchase I delay the decision. & .85 \\
\hline & Sometimes it is difficult to arrive at a decision when making a purchase. & .80 \\
\hline & Sometimes the choice in a store is so large that a purchase takes longer than expected. & .77 \\
\hline & Sometimes one postpones a planned purchase. & .75 \\
\hline & Eigenvalue $=2.51 \quad$ Total variance explained $=62.85$ & \\
\hline
\end{tabular}

각 변수와 측정변수들간의 회귀계수가 모두 유의 하게 나타났다 $(p<.000)$. 적합성 결과는 〈Table 2 〉와 같다. 의사결정 연기를 제외한 모든 변수들은 10 이상의 수정지수(modification index)가 나오지 않았 으나, 구매연기는 10 이상의 수정지수가 한 개 나 타났다. 그러나 본 연구의 목적이 가설화된 모형의 검증에 있고, 척도의 타당성을 검증하는 것이 아니 기 때문에 수정지수로 인한 측정오차 간에 공분산 을 설정하지 않았다. 따라서 수정지수에 의해 공분
산을 설정하지 않아서 의사결정 연기의 경우 여러 적합성지수 중에서 90 이하를 보이는 것은 별 문 제시 되지 않는다고 본다. 또한 $\mathrm{Bae}(2011)$ 에 의하 면 잠재변수는 최소한 세 개의 관측변수가 있어야 모형이 식별 가능하다고 보는데, 두 개의 측정변수 로 구성된 유사성 혼란은 이러한 측정모형의 식별 조건에 위배된다. 따라서 유사성 혼란은 적합성 지 수가 산출되지 않았으나, 탐험적 요인분석에 의해 요인부하량이 모두 .90 이상, 설명력이 $81.34 \%$, 신

$\langle$ Table 2〉 Fit statistics for measures

\begin{tabular}{l|c|c|c|c|c|c|c}
\hline \multicolumn{1}{c|}{ Measures } & $\chi^{2}$ & $p$ & RMR & GFI & AGFI & TLI & CFI \\
\hline Ongoing search behavior & 8.98 & .01 & .03 & .99 & .93 & .90 & .97 \\
\hline Overchoice confusion & 42.98 & .00 & .07 & .93 & .66 & .75 & .92 \\
\hline Similarity confusion & & .00 & .00 & 1.00 & & & 1.00 \\
\hline Decision postponement & 25.88 & .00 & .04 & .96 & .82 & .82 & .94 \\
\hline
\end{tabular}


뢰성 계수가 .77로 나타났으므로 유사성 변수를 포 함하여 제시된 모형의 적합성을 분석하는데 문제 가 되지 않는다고 본다.

확인적 요인분석 결과, 모든 변수들의 $\chi^{2}$ 값이 .05 이하로 통계적으로 유의하게 나타났다. 그러나 RMR은 과잉선택 혼란만 제외하고 .05 이하로 나타 났다. 지속적 탐색행동은 다른 적합성 지수(GFI, AGFI, TLI, CFI)가 모두 .90 이상으로 나타났다. 과잉선택 혼란의 경우, RMR은 .05 이상으로 나타났으나, AGFI 와 TLI는 최저의 적합성 수준인 .90보다 낮게 나타 났다. 그러나 GFI와 CFI의 지수는 최저의 적합수준 인 .90 이상으로 나타났다. 의사결정 연기도 과잉선 택 혼란과 같이 AGFI와 TLI는 최저의 적합성 수준 인 .90보다 낮게 나타났으나, GFI와 CFI의 지수는 최저의 적합수준인 .90 이상으로 나타났다. $\mathrm{Bae}(2011)$ 에 의하면 일반적으로 표본크기에 민감하지 않은 CFI가 적합성지수로 많이 이용한다고 하였다. 따라 서 과잉선택 혼란과 의사결정 연기의 CFI가 .90 이 상보다 다소 높게 나타나서 $\mathrm{GFI}$ 와 $\mathrm{AGFI}$ 가 .90 이 하로 낮게 나타나도 문제시 되지 않는다고 본다. 특히 의사결정 연기의 경우는 10 이상의 수정지수 에 대한 공분상을 허용하지 않았으므로 낮은 적합 성 지수가 더욱 문제시되지 않는다. 이상의 결과에 의해 모든 척도의 적합성에는 문제가 없다고 본다. 따라서 본 연구에서 사용한 변수들로 제시한 모형
을 검증하는데 적합한 것으로 분석된다.

\section{Hypothesized relationship test}

모형의 가설적 관계를 검증하기 위해 구조방정 식을 이용하여 분석하였다. 산출된 10 이상의 수정 지수에서 큰 값 순으로 공분산을 허용하여 수정모 형의 적합도를 산출하였다. 수정 후 가설에 의해 설정된 경로가 유의하지 않은 것을 삭제한 후 구조 방정식모형 분석을 다시 실시하였다. 최종 수정된 모형의 적합도는 〈Table 3〉과 같으며, 유의한 표준 화 경로계수(regression weights)와 설명력을 제시한 것은 〈Fig. 2〉와 같다.

최종 모형에 대한 적합성 결과를 보면(Table 3), $\chi^{2}$ 값이 .05 이하로 통계적으로 유의하게 나타났으 며, RMR은 .05 이상으로 나타났다. 그러나 자유도 의 증감에 따른 $\chi^{2}$ 의 변화를 보여주는 $\mathrm{Q}$ 값은 3 보 다 적어야 하는데 2.11로 나타났다. 또한 다른 적합 성 지수(GFI, AGFI, TLI, CFI)가 모두 최저 적합성 기준인 .90 이상으로 나타났다. 특히 적합성 지수로 많이 사용하는 CFI가 .95로서 적합성지수 중 가장 높게 나타났다. 따라서 최종모형을 채택하여 패스 트 패션 브랜드의 구매 의사결정 연기의 유의한 선 행변수를 살펴보았다.

최종모형에서 선택과잉 혼란과 구매 의사결정 연 기의 다중상관자승(squared multiple correlation: $R^{2}$ )

〈Table 3〉 Fit statistics for model in Fig. 2

\begin{tabular}{c|c|c|c|c|c|c|c|c}
\hline Measures & $\chi^{2}$ & $P$ & $Q$ & RMR & GFI & AGFI & TLI & CFI \\
\hline$N=305$ & 147.57 & .00 & 2.11 & .06 & .94 & .91 & .93 & .95 \\
\hline
\end{tabular}

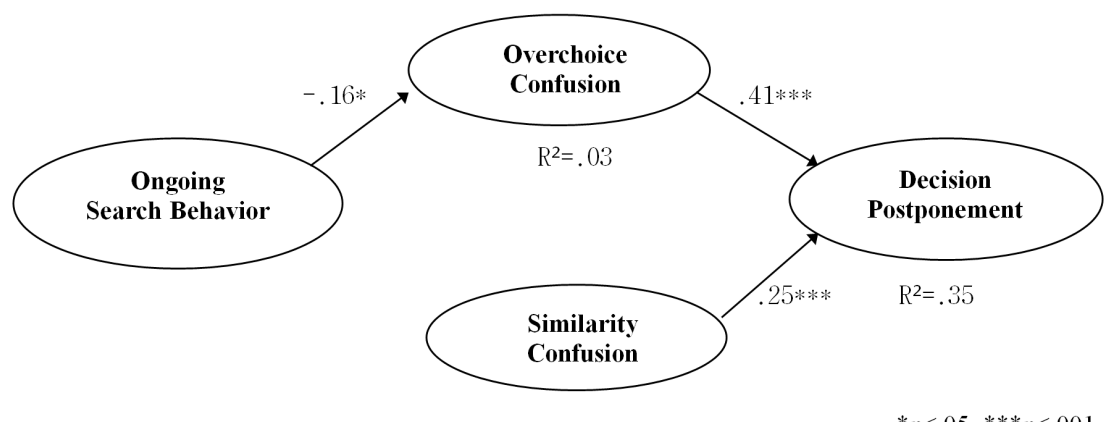

〈Fig. 2〉 Path coefficient in the hypothesized model 
은 각 선행변수에 의한 설명력을 의미한다. 선택과 잉 혼란은 $3 \%$ 가 지속적 탐색행동에 의해, 의사결 정 연기는 $35 \%$ 가 지속적 탐색, 선택 과잉 혼란, 유 사성 혼란에 의해 설명되고 있음을 알 수 있다. 선 택과잉 혼란은 지속적 탐색행동에 의한 설명력이 다소 낮게 나타났다. 그러나 최종변수인 의사결정 연기에 대한 $30 \%$ 이상의 비교적 높은 분산은 본 모형에 포함된 선행변수들에 의해 어느 정도 설명 되고 있다는 것을 나타낸다. 따라서 선행변수들에 의한 최종변수의 $30 \%$ 이상의 설명력과 함께 〈Table $3\rangle$ 의 높은 적합도는 본 연구모형이 잘 개념화되었 다는 것을 의미한다. 또한 〈Fig. 2〉를 보면, 선행변 수들이 의사결정 연기에 이르는 유의한 경로계수 가 지속적 탐색행동에서 선택과잉 혼란에 이르는 경로계수 $(-.16, p<.05)$ 를 제외하고, 모두 .30에 가 깝거나, 그 이상으로 나타난 결과도 연구모형이 잘 개념화 되었다는 것을 지지한다.

최종 모형의 유의한 경로계수를 보면, 〈Fig. 2〉와 같이 지속적 탐색행동에서 유사성 혼란과 지속적 탐색에서 구매 의사결정 연기에 이르는 경로를 제 외하고, 모든 경로는 유의하였다 $(p<0.001)$. 따라서 가설 1-1과 가설 2-1, 2-2는 채택되었고, 가설 1-2, $1-3$ 은 기각되었다. 소비자의 지속적 탐색행동은 패 스트 패션 브랜드의 선택과잉으로 인한 혼란을 통 해 패스트 패션 브랜드의 구매 의사결정 연기에 간 접적 영향을 주는 것으로 나타났다. 또한 유사성 혼란은 패스트 패션 브랜드의 구매 의사결정 연기 에 영향을 주는 것으로 나타났다. 이상의 결과는 소비자가 패션에 대한 지속적 탐색행동을 할수록 패스트 패션 브랜드의 선택과잉으로 혼란을 느끼 지 않으며, 결과적으로 의사결정을 연기하지 않는 것으로 나타났다. 또한 패스트 패션 브랜드에 대한 유사성 혼란을 느낄수록 구매 의사결정을 연기하 는 것으로 나타났다 유의적인 경로에 대한 구체적 인 논의는 다음과 같다.

첫째, 지속적 탐색행동은 선택과잉 혼란에 유의 한 부적 영향을 주었으나, 유사성 혼란에는 유의한 영향을 주지 않았다. 지속적 탐색이 선택과잉 혼란 에 부적 영향을 준 결과는 패션제품에 대해 지속적 탐색을 하는 소비자는 넘쳐나는 패스트 패션 브랜 드와 패스트 패션 브랜드의 과다한 제품, 매장, 정
보에 의해 혼란을 느끼지 않는다는 것을 의미한다. 이러한 결과는 지속적 탐색을 하는 소비자는 패스 트 패션 브랜드에 대한 모든 것을 파악하고 있어서, 기업에 부정적인 결과를 초래하는 선택초과잉을 느 끼지 않으므로, 이들을 대상으로 다른 마케팅적 접 근이 필요하다는 것을 시사한다. Schweizer et al. (2006)과 Iyengar and Lepper(2000)가 강조한 바와 같이, 현대사회의 마케팅에서 선택초과잉이 심각한 문제이나 패션에 대한 지속적 탐색을 하는 소비자 는 선택초과잉에 대한 예외적인 소비자임을 나타 낸다. 따라서 패스트 패션 브랜드의 마케터는 지속 적 탐색행동이 강한 소비자와 아닌 소비자를 대상 으로 선택초과잉에 대한 마케팅 전략을 다르게 전 개하여야 함에 유념해야 한다. 또한 지속적 탐색행 동이 선택과잉 혼란에 주는 영향을 밝힌 선행연구 가 전혀 없었으므로 연구에서 나타난 부적 영향은 학문적으로 의의가 매우 크다. 따라서 후속연구는 이를 바탕으로 다양한 제품의 구매에서도 부적 영 향을 나타내는지 밝힐 필요가 있다. 또한 지속적 탐색이 유사성 혼란에 유의한 영향을 보이지 않은 결과는 연구대상의 성향에 기인한 것으로 보인다. 연구대상의 유사성 혼란의 평균이 3.24 로서 다른 변수보다는 다소 높게 나타났다. 따라서 지속적 탐 색과 상관없이 유사성 혼란을 모두 높게 지각하고 있기 때문인 것으로 추론할 수 있다. 따라서 지속 적 탐색이 유사성 혼란에 미치는 영향의 유의성을 파악하기 위해서는 연구대상을 다르게 진행할 필 요가 있다.

둘째, 선택과잉 혼란이 구매 의사결정 연기에 정 적인 영향을 보인 결과는 수많은 패스트 패션 브랜 드들이 과잉 매장과 제품, 정보로 접근할수록 소비 자는 혼란을 느끼고, 구매 의사결정을 연기한다는 것을 의미한다. 선택과잉 혼란이 구매 의사결정 연 기에 정적 영향을 보인 결과는 의류학에서 선행연 구가 없으므로 의미가 크다고 본다. 다양한 제품에 대한 선택과잉에 대한 부정적인 결과에 대한 선행 연구들(Iyengar \& Lepper, 2000; Schweizer et al., 2006; Walsh et al., 2007; Wang \& Shukla, 2013))과 같이, 패스트 패션 브랜드도 선택의 폭이 넓을수록 구매할 가능성이 더 낮다는 것을 의미한다. 즉, 소 비자는 선택을 위한 대안들을 많이 가질수록 자신 
들의 선택에 대한 확신이 줄어들고, 결국에는 의사 결정을 연기하게 된다는 Chernev(2003)의 주장이 패스트 패션 브랜드의 구매에 있어서도 적용됨을 실증적으로 보여준다. 또한 대부분의 선행연구들이 제품 과잉혼란과 정보 과잉혼란에 초점을 두고 행 하여진 결과였으나, 본 연구에서는 브랜드, 매장, 제품, 정보에 대한 과잉혼란을 모두 포함하는 포괄 적인 선택과잉으로 보고 행하여진 결과라는 것에 도 의의가 있다.

셋째, 유사성 혼란이 구매 의사결정 연기에 정적 영향을 보인 결과는 유사성 혼란을 겪는 소비자들 은 '저가 제품 구매'와 같은 자기만의 체험적인 의 사결정 방법을 이용하므로 의사결정 연기를 하지 않는다고 밝힌 Walsh et al.(2007)의 결과와 상반된 다. Walsh et al.(2007)의 연구가 고가와 저가의 브 랜드로 한정하여 구매행동에 미치는 영향을 본 반 면, 본 연구는 품질의 차이가 없는 비슷한 가격의 패스트 패션 브랜드들로 한정하여 구매행동에 미 치는 영향을 보았기 때문에 상반된 결과가 나타난 것으로 유추할 수 있다. 따라서 유사성 혼란으로 인해 구매를 포기하고, 최종 결과는 선택에 대한 자신감의 감소라는 Mitchell et al.(2005)의 주장을 실증적으로 보여주었다는데 의의가 크다.

넷째, 지속적 탐색과 소비자혼란을 통해 패스트 패션 브랜드 구매 의사결정 연기에 이르는 유의한 경로를 보면, 지속적 탐색행동이 의사결정 연기에 직접적인 영향을 주지 않지 않는 것으로 나타났다. 그러나 소비자 혼란 중 선택과잉 혼란을 통해 간접 적인 영향을 주는 것으로 나타났다. 즉, 지속적 탐 색을 할수록 선택과잉 혼란을 느끼지 않으며, 결과 적으로 의사결정을 연기하지 않는다는 것을 의미 한다. 이러한 결과는 선택과잉 혼란이 의사결정 연 기에 중요한 변수임을 나타낸다. 또한 지속적 탐색 이 유사성 혼란을 통해 의사결정 연기에 간접적 영 향을 주지 않고, 유사성 혼란이 의사결정 연기에 유의한 영향을 미치는 결과는 유사성 혼란이 중요 한 변수임을 나타낸다. 따라서 전체적인 유의 경로 는 소비자 혼란인 선택과잉 혼란과 유사성 혼란이 구매 의사결정 연기에 중요한 변수임을 의미한다. 따라서 마케터는 의사결정 연기에 유의한 영향을 주는 소비자 혼란의 중요성을 인식하고, 소비자 혼
란을 줄일 수 있는 전략을 수립하여야 한다. 또한 지속적 탐색행동이 선택과잉 혼란을 통해 패스트 패션 브랜드 구매 의사결정 연기에 유의적인 영향 을 미친 결과는 Park(2014)의 지속적 탐색행동이 패스트 패션 브랜드의 구매태도에 유의적인 영향 을 주지 않은 결과에 대한 이해를 제시한다. $\operatorname{Park}(2014)$ 의 연구에서 패스트 패션 브랜드의 구매 에 영향을 주는 변수로서 중요한 변수인 선택과잉 혼란을 포함하지 않았기 때문으로 유추할 수 있다. 따라서 패스트 패션 브랜드에 대한 소비자 이해를 제시하기 위한 후속연구는 소비자 혼란의 다양한 변수들을 포함하여야 할 것이다. 또한 소비자 소비 자 혼란의 선택과잉 혼란과 유사성 혼란 모두 의사 결정 연기에 유의적인 영향을 주었는데, 상대적 영 향력을 보면, 과잉선택 혼란(경로계수=.41)이 유사 성 혼란(경로계수=.25)보다 더 크게 나타났다. 따라 서 마케터는 소비자 혼란 중에서도 과잉선택 혼란 의 중요성을 더 인식할 필요가 있다.

\section{Conclusion}

글로벌 브랜드들의 국내 진출과 함께 국내 브랜 드들의 시장진입으로 인해 패스트 패션 시장은 과 포화 현상을 보여주고 있다. 더욱이 수 많은 패스 트 패션 브랜드들이 과다한 매장, 제품, 정보와 함 께 최신유행을 반영한 유사한 제품들을 일시적으 로 소비자에게 제시함으로써 선택과잉과 유사성이 라는 심각한 문제점을 보여주고 있다. 따라서 본 연구는 패스트 패션 브랜드의 문제점이 소비자의 구매행동에 미치는 영향을 밝히고, 앞으로의 패스 트 패션 시장에 대한 논의와 함께 경쟁력을 위한 효과적인 마케팅 전략을 제안하고자 하였다. 패스 트 패션 브랜드의 구매행동으로 구매 의사결정 변 수를 선정하였으며, 선행변수로서 패스트 패션 브 랜드의 선택과잉 혼란, 유사성 혼란과 함께 지속적 인 탐색행동을 선정하였다. 본 연구는 소비자의 패 션에 대한 지속적 탐색행동이 패스트 패션 구매 의 사결정 지연에 직접적인 영향을 줄 뿐 아니라, 선 택과잉 혼란과 유사성 혼란을 통해 간접적인 영향 을 준다는 경로를 설정하고, 이를 검증하였다.

연구결과에 의한 결론은 다음과 같다. 
첫째, 패션에 대한 지속적 탐색행동을 할수록 패 스트 패션 브랜드의 선택과잉으로 인한 혼란을 느 끼지 않게 나타난 결과는 패스트 패션 브랜드 성장 에 한계가 있음을 제시한다. 소비자가 지속적 탐색 을 해야만 패스트 패션 브랜드의 선택과잉으로 인 한 혼란을 덜 겪는데, 소비자의 지속적 탐색행동은 마케팅 자극에 의해 높이는 것에는 한계가 있기 때 문이다. 따라서 패스트 패션 브랜드의 계속적 성장 을 위하여 마케터는 소비자의 지속적 탐색의 차이 에 따라 다음과 같은 차별화된 전략을 실시하여야 한다. 지속적 탐색을 하는 패션지향적인 소비자를 목표로 하는 경우, 소비자에게 끓임없이 구체적인 브랜드, 매장, 제품, 정보를 제시하는 전략이 유효 하다. 그러나 지속적 탐색을 하지 않는 일반적인 소비자를 대상으로 할 경우에는 선택과잉 혼란을 감소시키기 위한 다음의 전략이 효과적이다. 제품 전략으로는 패스트 패션 브랜드의 중요한 전략인 소량 다품종을 더 이상 강화하지 않아야 할 것이다. 포화된 패스트 패션 시장에서 경쟁력을 높이기 위 해 소량 다품종의 제품전략을 더 강화하면 지속적 탐색행동을 하지 않는 소비자에게 선택과잉 혼란 을 더 가중시켜서 부정적인 결과를 초래하게 될 것 이다. 제공하는 제품의 수보다는 향상된 품질과 차 별화된 디자인의 제품을 제시하는데 더 주력하여 야 한다. 촉진전략은 광고와 판매원을 통해 과다한 제품의 제시와 양적인 정보를 제공하지 않고, 광고 와 판매원을 통해 타 브랜드와는 차별화된 강력한 브랜드 이미지를 제시하여야 할 것이다. 또한 유통 전략은 매장 수를 확보하기 보다는 차별화된 매장 분위기를 제시하여야 할 것이다. 따라서 현재의 패 스트 패션 시장의 경쟁적 환경에서 과다한 양의 비 슷한 매장, 제품, 정보에 둘러 쌓여진 소비자에게 브랜드의 인지도를 높이고, 차별화된 이미지, 매장, 제품을 제시하여야 한다. 패스트 패션 브랜드 자체 가 패션 지향적인 소비자를 표적시장으로 하기 때 문에 선택과잉 혼란의 문제점을 심각하게 고려하 지 않을 수도 있으나, 패스트 패션 브랜드는 현재 의 경쟁적 환경과 시장성장으로 인해 패션지향적 이지 않은 소비자도 표적시장으로 하고 있다. 따라 서 마케터는 선택과잉 혼란이 심각한 의사결정 연 기 요인이라는 것을 인지하고, 지속적 정보탐색을
하는 소비자를 대상으로 하는 전략 외에도 정보탐 색을 하지 않는 소비자를 대상으로 하는 선택과잉 혼란을 감소시키는 전략을 병행하여 구사하여야 함을 유념해야 한다.

둘째, 선택과잉과 유사성 혼란이 구매의사결정 연기에 정적인 영향을 주는 것으로 나타난 결과도 패스트 패션 브랜드의 지속적인 성장에 한계가 있 다는 것을 의미한다. 왜냐하면 패스트 패션이라는 특성으로 인해 패스트 패션 브랜드들은 유사한 브 랜드, 매장, 제품, 정보전략을 구사할 수밖에 없기 때문이다. 따라서 패스트 패션 브랜드들은 첫 번째 제시한 결론과 같이 최신유행을 반영하지만, 타 패 스트 패션 브랜드와는 다른 제품전략, 촉진전략, 유 통전략으로 차별성을 강조하지 않으면 포화상태의 패스트 패션 시장에서 경쟁력을 갖기 힘들 것이다. 또한 소비자 혼란의 선택과잉 혼란과 유사성 혼란 모두 의사결정 연기에 유의적인 영향을 주었는데, 과잉선택 혼란이 유사성 혼란보다 상대적 영향력 이 더 크게 나타난 결과는 마케터가 선택과잉 혼란 을 감소시키는 전략에 더 총력을 다하여야 함을 의 미한다.

셋째, 본 연구에서 소비자 혼란이 중요한 변수로 나타난 결과는 구매환경에 있어서 끊임없이 증가 하는 의사결정과 관련된 정보로 인해 소비자 혼란 은 중요한 문제가 되고 있다고 한 Mitchell and Papavassiliou(1999)의 주장을 지지한다. 특히 다양 한 선행연구들이 선택과잉과 유사성으로 인한 소 비자 혼란에 대한 문제점을 제시하고, 이에 대한 연구의 필요성을 강조하였는데, 패스트 패션 브랜 드의 구매의사결정 연기에 있어서 소비자 혼란이 유의한 중요변수임을 밝힌 것에 본 연구의 의의가 있다.

본 연구의 한계점과 이에 따른 후속연구에 대한 제언은 다음과 같다.

첫째, 본 연구에서 사용한 선행변수인 소비자 혼 란과 종속변수인 의사결정 연기에 대해서 의류학 뿐 아니라, 소비자학에서도 선행연구가 미흡해서 본 연 구의 결과와 비교, 논의하기에 한계가 있었다. 따라 서 소비자 혼란과 의사결정 연기에 대한 깊이 있는 이해를 위해 다양한 학문의 관점에서 다양한 변수와 의 관련성을 밝히는 후속연구가 이루어져야 한다. 
둘째, 본 연구는 급성장 중인 패스트 패션 브랜 드의 마케팅 전략의 유효함을 밝히기 위하여 의사 결정 연기의 선행변수로서 패스트 패션 브랜드의 특성에 관련된 변수만을 포함하였다. 후속연구는 연구대상이 되는 패션제품의 특성에 따른 차별적 마케팅 전략의 유효성을 밝힐 필요가 있다. 따라서 패스트 패션 브랜드 외에 다양한 패션 제품의 의사 결정 연기에 대한 유의한 선행변수를 밝히고, 선행 변수의 영향력의 차이를 제시하여야 할 것이다.

셋째, 최종모형에서 선택과잉 혼란의 다중상관자 승(.03)은 지속적 탐색행동에 의해 다소 낮은 설명력 을 보였다. 또한 지속적 탐색행동에서 선택과잉 혼 란에 이르는 경로계수( $-.16, p<.05)$ 도 소비자 혼란 에서 구매 의사결정 연기에 이르는 경로계수들보다 낮게 나타났다. 따라서 후속연구는 선택과잉 혼란에 영향을 주는 변수로 지속적 탐색행동 외에 패션 지 식과 같은 다양한 유의한 변수들을 포함한 결과로 높은 설명력과 경로계수를 얻을 수 있을 것이다.

넷째, 구매 의사결정 연기의 다중상관자승이 $35 \%$ 으로 $50 \%$ 보다 적게 나타났다. 따라서 후속 연 구는 더 다양한 변수를 포함하여 설명력이 높은 모 형을 제시, 밝혀야 할 것이다.

다섯째, 유사성 혼란에 지속적 탐색행동의 유의 한 영향을 미치지 않는 것으로 나타났다. 본 연구 는 지속적 탐색행동만을 선택과잉 혼란과 유사성 혼란에 유의한 영향을 주는 선행변수로 포함하였 으나, 후속연구는 지속적 탐색행동 외에 소비자 혼 란에 유의한 영향을 주는 다양한 변수를 포함하여 야 할 것이며, 밝히거나 또는 유의한 결과변수들 중에서 경로계수의 크기를 비교하여 중요한 영향 변수를 밝혀야 할 것이다.

여섯째, 본 연구는 국내 브랜드와 해외 브랜드의 구분 없이 소비자의 의사결정 연기의 선행변수를 밝 혔다. 따라서 후속연구는 국내 브랜드 또는 해외 브 랜드만을 대상으로 하여 소비자 의사결정 연기의 선 행변수를 밝히거나 국내와 해외 브랜드에 따른 의사 결정 연기의 선행변수 차이를 밝혀야 할 것이다.

\section{References}

A new alternative to the boring fast fashions.(2011,
February). Presian Biz. Retrieved September 5, 2014, from http://www.presian.com

Bae, B. R.(2011). Structural equation modeling with Amos 19: Principles and practice. Seoul: Chungram.

Balabanis, G., \& Craven, S.(1997). Consumer confusion from own brand lookalikes: An exploratory investigation. Journal of Marketing Management, 13(4), 299-313.

Bellenger, D. N., \& Korgaokar, P. K.(1980). Profiling the recreational shopper. Journal of Retailing, 56(3), 77-92.

Bloch, P. H., Sherrell, D. L., \& Ridgway, N. M. (1986). Consumer search: An extended framework. Journal of Consumer Research, 13(1), 119-126.

Byun, S. E., \& Sternquist, B.(2008). The antecedents of in-store hoarding: Measurements and application in the fast fashion retail environment. The International Review of Retail, Distribution and Consumer Research, 18(2), 133-147.

Chae, J. S.(2014, February 10). Efforts to clear the negative images of fast fashion. Hankookllbo. Retrieved September 5, 2014, from http://www. hankookilbo.com

Chernev, A.(2003). When more is less and less is more: The role of ideal point availability and assortment in choice. Journal of Consumer Research, 30(2), 170-182.

Choi, M. Y.(2010). A study on the explanatory variables of Internet ongoing information search behavior. Journal of the Korean Society of Clothing and Textiles, 34(9), 1527-1537.

Durvasula, S., Lysonski, S., \& Andrews, J. C.(1993). Cross-cultural generalizability of a scale for profiling consumers' decision-making styles. The Journal of Consumer Affairs, 27(1), 55-65.

Foxman, E. R., Gerger, P. W., \& Cote, J. A.(1999). Consumer brand confusion: A conceptual framework. Psychology \& Marketing, 9(2), 123-141.

Greenleaf, E. A., \& Lehmann, D. R.(1995). Reasons for substantial delay in consumer decision making. 
Journal of Consumer Research, 22(2), 186-199. Hassan, L., Shaw, D., Shiu, E., Walsh, G., \& Parry, S. (2013). Uncertainty in ethical consumer choice: A conceptual model. Journal of Consumer Behaviour, 12(3), 182-193.

Huffman, C., \& Kahn, G. E.(1998). Variety for sale: Mass customization or mass confusion? Journal of Retailing, 74(4), 491-513.

Iyengar, S. S., \& Lepper, M. R.(2000). When choice is demotivating: Can one desire too much of a good thing? Journal of Personality and Social Psychology, 79(6), 995-1006.

Jacoby, J., \& Morrin, M.(1998). "Not manufactured or authorized by...": Recent federal cases involving trademark disclaimers. Journal of Public Policy \& Marketing, 17(1), 97-107.

Jang, H. M.(2014, September 1). Zara leads the trend by marketing new merchandises twice a week all over the world. HankookIlbo. Retrieved September 5, 2014, from http://www.hankookilbo.com

Kang, J. H., \& Sung, Y. Y.(2010). The impact of information technology on the process innovation and competitiveness in the fashion industry: Case study of fast fashion ZARA. Journal of the Korean society of Clothing and Textiles, 34(1), 1-13.

Kapferer, J. N.(1995). Brand confusion: Empirical study of a legal concept. Psychology \& Marketing, 12(6), 551-568.

Kim, H. N.(2008). The effects of clothing benefits on delay of decision making and shopping information in Internet shopping. Journal of the Korean Society of Clothing and Textiles, 32(5), 766-776.

Kim, J. H., \& Lee, Y. R.(2011). Influence of perceived similarity on fashion brand extension: Exploring the moderating effect of brand relationship quality. Journal of the Korean Society of Clothing and Textiles, 35(7), 721-735.

Kim, S. H.(2007). A study on the fast fashion(Part II): Focusing on clothing selection criteria and store selection criteria. The Research Journal of the Costume Culture, 15(5), 888-901.
Kim, S. H., \& Rhee, Y. S.(2001). A study onf the relationship between the fashion leadership and the characteristics of the shopping-related behavior. Journal of the Korean Society of Clothing and Textiles, 25(1), 162-172.

Langer, A., Eisend, M., \& Kuß, A.(2008). The impact of eco-labels on consumers: Less information, more confusion? Proceedings of European Conference of Association for Consumer Research, 8, 338339.

Lee, E. J.(2013). The effects of Internet fashion consumer's anticipated regret and selection difficulty on decision making delay and purchase switching intention. Journal of the Korean Society of Clothing and Textiles, 37(4), 526-539.

Lim, S. M., Choi, J. Y., \& Kim, M. S.(2008). A study on the strategies of the fashion industry toward fast fashion. The Research Journal of the Costume Culture, 16(3), 432-443.

Loken, B., Ross, I., \& Hinkle, R. L.(1986). Consumer "confusion" of origin and brand similarity perceptions. Journal of Public Policy \& Marketing, 5(1), 195-211.

Matzler, K., Stieger, D., \& FÜller, J.(2011). Consumer confusion in Internet-based mass customization: Testing a network of antecedents and consequences. Journal of Consumer Policy, 34(2), 231-247.

Miaoulis, G., \& D'amato, N.(1978). Consumer confusion $\&$ trademark infringement. Journal of Marketing, 42(2), 48-55.

Mick, D. G., Broniarczyk, S. M., \& Haidt, J.(2004). Choose, choose, choose, choose, choose, choose, choose: Emerging and prospective research on the deleterious effects of living in consumer hyperchoice. Journal of Business Ethics, 52(2), 207211.

Mitchell, V. W., \& Papavassiliou, V.(1999). Marketing causes and implications of consumer confusion. Journal of Product \& Brand Management, 8(4), 319-339.

Mitchell, V. W., Walsh, G., \& Yamin, M.(2005). 
Towards a conceptual model of consumer confusion. Advances in Consumer Research, 32(1), 143-150.

Parbha, C., Connaway, L. S., Olszewski, L., \& Jenkins, L. R.(2007). What is enough? Satisfaction information needs. Journal of Documentation, 63(1), 74-89.

Park, H. J.(2013). The antecedents of purchasing fast fashion brands. The Research Journal of the Costume Culture, 21(6), 827-843.

Park, H. J.(2014). The influences of fashion consciousness, eco-fashion consumption decision, ongoing search behavior, shopping enjoyment on attitudes toward purchasing fast fashion brands. Journal of the Korea Fashion \& Costume Design Association, 16(2), 111-126.

Reamy, D. W., \& Arrington, D. W.(2014). Fashionomics (J. Yu, S. Shin, H. Park, S. Im, \& M. Kim, Tans). Seoul: Sigmapress. (Original work published 2013)

Rhee, Y. J.(2009). Difference in extended products evaluation by consumer innovativeness and similarity of product category for apparel brand extension. Journal of the Korean Society of Clothing and Textiles, 33(10), 1622-1632.

Sachse, M., Drengner, J., \& Jahn, S.(2010). Negative effects of event sponsoring and ambushing: The case of consumer confusion. Proceedings of North American Conference of Association for Consumer Research, 37, 546-547.

Schweizer, M., Kotouc, A. J., \& Wagner, T.(2006). Scale development for consumer confusion. Advances in Consumer Research, 33(1), 184-190.

Settle, R. B., \& Alreck, P. L.(1988). Hyperchoice shapes the marketplace. Marketing Communications, 13(5), 15-20.

Sproles, G. B., \& Kendall, E. L.(1986). A methodo- logy for profiling consumers' decision-making styles. The Journal of Consumer Affairs, 20(2), 267-279.

Tauber, E. M.(1972). Why do people shop? Journal of Marketing, 36(4), 46-59.

Thompson, D. V., Hamilton, R. W., \& Petrova, P. K. (2009). When mental simulation hinders behavior: The effects of process-oriented thinking on decision difficulty and performance. Journal of Consumer Research, 36(4), 562-574.

Turnbull, P. W., Leek, S., \& Ying, G.(2000). Customer confusion: The mobile phone market. Journal of Marketing Management, 16(1-3), 143-163.

Walsh, G., Mitchell, V. W., Kilian, T., \& Miller, L. (2010). Measuring consumer vulnerability to perceived product-similarity problems and its consequences. Journal of Marketing Management, 26(1/2), 146-162.

Walsh, G., Hennig-Thurau, T., \& Mitchell, V. W.(2007). Consumer confusion proneness: Scale development, validation, and application. Journal of Marketing Management, 23(7/8), 697-721.

Wang, Q., \& Shukla, P.(2013). Linking sources of consumer confusion to decision satisfaction: The role of choice goals. Psychology and Marketing, 30(4), 295-304.

Warlop, L., Ratneshwar, S., \& Van Osselaer, Stijn M. J. (2005). Distinctive brand cues and memory for product consumption experiences. International Journal of Research in Marketing, 22(1), 27-44.

Watchravesringkan, K., \& Yurchisin, J.(2007). A structural analysis of value orientations, price perception and ongoing search behaviour: Across-cultural study of American and Korean consumers. International Journal of Consumer Studies, 31(3), 272-282. 